\title{
A new variety of spring soft wheat aist-45 as a result of a wide environmental test
}

\author{
E.A. Filippova*, L.T. Maltseva, N.Yu. Bannikova, I.A. Drobot, and N.V. Kataeva \\ FSBSI "Ural Federal Agrarian Research Center of the Ural Branch of the Russian Academy of \\ Sciences", Yekaterinburg, Russia
}

\begin{abstract}
The assessment of a new variety of spring soft wheat Aist 45 was given based on the analysis data of yield, plasticity, grain quality, and disease resistance. The studies were carried out at the Kurgan Scientific Research Institute of Agriculture, a branch of the Ural Federal Research Center of the Ural Branch of the Russian Academy of Sciences. A test in breeding nurseries (2011-2020) showed an excess of yield over mid-season and mid-late standards (4.4 and $2.8 \mathrm{cwt} / \mathrm{ha}$ ). In the ecological test under the KASIB (Kazakstan-Siberian network for improving spring wheat) program of 52 varieties in 16 points of Russia and Kazakhstan (2017-2018), Aist 45 variety had a high rating in terms of yield; according to the results of technological analysis, it showed good potential in the content of protein $(15.7-16,3 \%)$ and gluten in grain $(31.6-32.4 \%)$, attributed to valuable wheat. When evaluated for resistance to brown rust against an artificial background in the seedling phase, Aist 45 was assigned to the resistant type (VIZR and VNIIF). Against the infectious background of the RIBSP of South Kazakhstan, the variety showed resistance to septoriosis and pyrenophorosis. Susceptible to dust brand. The variety is capable of forming a stable yield in drought stress conditions and epiphytotic development of brown and stem rust.
\end{abstract}

\section{Introduction}

In the Trans-Urals, the main grain crop is spring soft wheat, which is sown on about a million hectares. Western Siberia is a region with risky conditions for stable wheat grain production. Natural and climatic conditions in this region are distinguished by exceptional diversity, severity and variability in time and space [1]. When producing grain in difficult climatic conditions, preference should be given to varieties with high adaptability, plasticity and resistance to biotic factors. The presence of such traits is most characteristic of zoned and local varieties, the selection and evaluation of which took place over a long period in specific conditions, covering the whole variety of emerging weather phenomena [2]. The variety remains one of the most accessible, low-cost and most effective factors for stabilizing and increasing grain production and improving its quality [3].

In comparison with previously zoned varieties, new ones can make fuller use of moisture, elements of mineral nutrition and other factors of plant life. However, there are

\footnotetext{
* Corresponding author: info@kurganniish.ru
} 
no universal varieties that are equally suitable for all backgrounds and conditions. Therefore, the identification of the productivity potential, the norms of varieties' reaction to intensification factors in modern conditions of climate change is the most important condition for varietal technologies' development, improving the techniques and methods of managing the productivity of grain crops [4]. Through the "prism" of ecological variety testing, the breeder is given the opportunity to compare the results of his work with the achievements of other researchers, if necessary, eliminate the shortcomings identified in the created material, timely expand seed production based on promising varieties and possibly use the material under study as sources of economically valuable traits and properties [5].

\section{Materials and Methods}

The studies were carried out at Kurgan Research Institute of Agriculture, a branch of FSBSI UFARC UB RAS in the wheat breeding laboratory within the framework of the State Order of the Ministry of Science and Higher Education in direction 150. "Development and improvement of breeding methods, creation of source material and adaptive varieties of cereals, legumes, fodder, fruit and berry, ornamental crops and potatoes" (state order No. 0773-2019-0022). № 0532-2021-0008

The research material was a new variety of spring soft wheat Aist 45. The observations were carried out in accordance with the Methodology for State Variety Testing [6]. The sowing period - the end of the 2nd and 3rd decade of May. The predecessor - fallow; additionally, provocative backgrounds were used: sowing on stubble and late sowing (June 10) to assess grain plumpness at low temperatures and resistance to stem rust, which usually appears on late sowing [7].

Kurgan Research Institute of Agriculture - forest-steppe zone, annual precipitation $366 \ldots 425 \mathrm{~mm}$, the sum of positive temperatures $-2350 \ldots 2380{ }^{0} \mathrm{C}$. The soil of the experimental site is leached light chernozem with a humus content in the arable layer $(0 \ldots$ $20 \mathrm{~cm}$ ) $-4.26 \%$ (according to Tyurin); $\mathrm{pH}_{\text {water }}-5.7$; the content of mobile $\mathrm{P}_{2} \mathrm{O}_{5}$ (according to Chirikov) - $118 \mathrm{mg} / \mathrm{kg}$ of soil, exchange $\mathrm{K}_{2} \mathrm{O}-217 \mathrm{mg} / \mathrm{kg}$ of soil, nitrate nitrogen $\mathrm{N}^{-\mathrm{NO}_{3}}$ - $14 \mathrm{mg} / \mathrm{kg}$ of soil.

The weather conditions during the observation period differed in contrast: from a severe drought of the June - July period $(2012,2020)$ with a low precipitation rate of $22-31 \%$ $(\mathrm{HTC}=0.4)$ to an excess of moisture $(2011)$ with a provision of $148 \%(\mathrm{HTC}=1.2)$. The distribution of heat and moisture over the years was ambiguous with frequent manifestations of arid phenomena in different phases of plant development. Weather conditions in the summer period of 2015, 2016 and 2017, provoking an outbreak of brown and epiphytotic stem rust, were important for assessing disease resistance. In July 2015, 90 $\mathrm{mm}$ of precipitation have fallen (150\% of the norm) with an average daily air temperature of $18^{\circ} \mathrm{C}$. In 2016 , July was warm and humid - $130.6 \mathrm{~mm}(241.8 \%)$, temperature $-19.6^{\circ} \mathrm{C}$. June 2017 was characterized by enough moisture and a temperature of 15.4-19.3 ${ }^{\circ}$. Moisture in the 1 st and 3rd decades of July was above the norm (243 and 104\%). According to the classification of the All-Russian Research Institute of Phytopathology, the weather conditions prevailing in these years were favorable for the spread of leaf infections.

Purpose of research: To assess the new Aist 45 variety of spring soft wheat for use as a source material in breeding based on the analysis of yield, plasticity, grain quality, disease resistance and actual widespread introduction into production. 


\section{Results and Discussion}

Parentage of Aist 45 variety - individual selection from a combination of crossing Lyubava 2 / Prokhorovka (breeding number D-22-17). Type - lutescense. The variety is of a midseason type, the growing season is 80-87 days, at the level of Terzia and Gerakl standards. Medium-sized, in years with favorable moisture supply the height of plants reaches 100$110 \mathrm{~cm}$. Lodging resistance - 4-5 points, 0.5 points higher than Terzia. The ear is large, well-grained.

A long-term test in breeding nurseries of different levels (2011-2020) showed a steady excess of Aist 45 variety yield over the mid-ripening and mid-late standards (on average by 4.4 and $2.8 \mathrm{cwt} / \mathrm{ha}$ ), incl. both in a dry year (2012) and in a wet year (2011) (Table 1).

Table 1. Productivity of Aist 45 variety in comparison with the standards, cwt/ha, 2011-2020.

\begin{tabular}{|c|c|c|c|c|c|c|c|}
\hline \multirow[b]{2}{*}{ Year } & \multirow[b]{2}{*}{ Aist 45} & \multirow{2}{*}{$\begin{array}{c}\text { St No.1 } \\
* \\
\text { medium- } \\
\text { ripe }\end{array}$} & \multirow{2}{*}{$\begin{array}{l}\text { St No. } 2 \\
* * \\
\text { medium- } \\
\text { late }\end{array}$} & \multicolumn{3}{|c|}{ Stork $45, \pm \mathrm{c}$} & \multirow[b]{2}{*}{$\begin{array}{l}\text { LSD } 05 \\
\text { cwt/ha }\end{array}$} \\
\hline & & & & St No. 1 & St No. 2 & average & \\
\hline 2011 & 46.6 & 40.3 & 45.5 & 6.3 & 1.1 & 3.7 & 3.3 \\
\hline 2012 & 12.6 & 10.0 & 8.0 & 2.6 & 4.6 & 3.6 & 3.0 \\
\hline 2013 & 21.0 & 18.8 & 20.7 & 2.2 & 0.3 & 1.2 & 1.0 \\
\hline 2014 & 26.0 & 24.0 & 21.0 & 2.0 & 5.0 & 3.5 & 2.9 \\
\hline 2015 & 27.4 & 22.5 & 20.8 & 4.9 & 6.6 & 5.7 & 3.4 \\
\hline 2016 & 32.6 & 24.7 & 28.6 & 7.9 & 4.0 & 5.9 & 3.5 \\
\hline 2017 & 43.5 & 35.8 & 41.9 & 7.7 & 1.6 & 4.6 & 3.1 \\
\hline 2018 & 32.9 & 32.0 & 32.0 & 0.9 & 0.9 & 0.9 & 1.0 \\
\hline 2019 & 28.7 & 25.5 & 26.9 & 3.2 & 1.8 & 2.5 & 2.0 \\
\hline 2020 & 23.3 & 17.2 & 21.4 & 6.1 & 1.9 & 4.0 & 3.2 \\
\hline Average & 29.5 & 25.1 & 26.7 & 4.4 & 2.8 & 3.6 & 2.6 \\
\hline
\end{tabular}

* St No.1. Mid-season - Tertzia, from 2019 Gerakl

** St №2. Medium-late - Omskaya 35, from 2018 - Uralosibirskaya

The greatest excess was reached during the epiphytotic years of brown and stem rust in 2016-2017. (7.7-7.9 cwt/ha), when the Terzia standard has lost its stability. A test on hard provocative backgrounds with stubble sowing and late sowing (June 10) showed a higher endurance of the variety in comparison with the standards (table 2).

Table 2. Productivity of Aist 45 variety on provocative backgrounds, CVT, 2017-2020, cwt/ha.

\begin{tabular}{|l|c|c|c|c|c|c|}
\hline \multicolumn{1}{|c|}{ Variety } & 2017 & 2018 & 2019 & 2020 & $\overline{\mathrm{x}}$ & $\begin{array}{c}\text { Aist 45, } \pm \mathrm{c} . \\
\text { St }\end{array}$ \\
\hline \multicolumn{7}{|c|}{ Stubble sowing } \\
\hline Aist 45 & 36.1 & 15.8 & 14.6 & 5.6 & 22.2 & \\
\hline Terzia, st & 35.2 & 18.2 & 12.7 & 5.3 & 22.0 & 0.2 \\
\hline Gerakl, st & - & - & 13.4 & 4.5 & 8.9 & 1.2 \\
\hline \multicolumn{7}{|c|}{ Late sowing date (June 10) } \\
\hline Aist 45 & 20.4 & 29.3 & 26.5 & 7.0 & 25.4 & \\
\hline Terzia, st & 2.3 & 25.5 & 23.2 & 4.3 & 17.0 & 8.4 \\
\hline Gerakl, st & - & - & 25.1 & 2.1 & 13.6 & 3.1 \\
\hline
\end{tabular}

An ecological test of 52 varieties carried out under the KASIB program for 2 years (2017-2018) in 16 different geographical points of Russia and Kazakhstan showed a high rating of Aist 45 variety in terms of yield (rank 6,7,9), confirming its plasticity (table 3). 
Table 3. Productivity of Aist 45 variety in an ecological test, KASIB, 2017-2018.

\begin{tabular}{|c|c|c|c|c|c|c|c|}
\hline \multirow{3}{*}{$\begin{array}{l}\text { Point } \\
\text { trials }\end{array}$} & \multicolumn{4}{|c|}{ Productivity, cwt/ha } & \multirow{2}{*}{\multicolumn{3}{|c|}{ Rank }} \\
\hline & \multicolumn{2}{|c|}{ Aist 45} & \multicolumn{2}{|c|}{$\overline{\mathrm{x}}$ by 52 grades } & & & \\
\hline & 2017 & 2018 & 2017 & 2018 & 2017 & 2018 & $\overline{\mathrm{x}}$ \\
\hline \multicolumn{8}{|c|}{ Kazakhstan } \\
\hline Aktobe, AES & 12.7 & 11.1 & 14.4 & 13.6 & 37 & 38 & 40 \\
\hline Almaty region & 42.9 & 42.7 & 31.7 & 34.2 & 2 & 14 & 4 \\
\hline Karabalyk, AES & 28.9 & 40.6 & 17.3 & 39.9 & 9 & 24 & 10 \\
\hline Karaganda, AES & 12.0 & 20.2 & 12.1 & 21.5 & 22 & 34 & 34 \\
\hline Akmola, SPCG & 26.0 & 28.5 & 30.0 & 24.0 & 21 & 5 & 11 \\
\hline Pavlodar, AES & 15.7 & 18.7 & 15.9 & 18.8 & 32 & 25 & 25 \\
\hline Zhambyl RIBB & 40.5 & 40.4 & 34.7 & 35.1 & 14 & 14 & 14 \\
\hline \multicolumn{8}{|c|}{$\mathrm{RF}$} \\
\hline Altai RIA & 26.3 & 56.7 & 24.4 & 49.1 & 18 & 8 & 12 \\
\hline Kurgan RIA & 44.0 & 44.0 & 31.8 & 31.9 & 12 & 12 & 12 \\
\hline Kurgansemena & 52.0 & 48.4 & 38.8 & 47.6 & 7 & 12 & 12 \\
\hline RIA SE & 33.6 & 13.2 & 26.5 & 15.8 & 2 & 36 & 15 \\
\hline Omsk SAU & 35.3 & 22.8 & 30.3 & 20.3 & 5 & 16 & 7 \\
\hline Novosibirsk, RIPCB & 44.0 & 60.5 & 31.8 & 40.3 & 12 & 7 & 8 \\
\hline Omsk, SibRIA & 36.5 & 61.3 & 37.9 & 47.8 & 26 & 4 & 14 \\
\hline Chelyabinsk, RIA & 53.6 & 39.4 & 40.7 & 34.7 & 4 & 15 & 4 \\
\hline Tyumen SAU & 21.9 & 38.7 & 24.1 & 40.2 & 30 & 37 & 31 \\
\hline General rank in KASIB & 31.4 & 35.3 & 27.2 & 31.8 & 6 & 7 & 9 \\
\hline Standard deviation, $\mathrm{Q}$ & & & 3.7 & 2.9 & & & \\
\hline Variation coefficient, $\%$ & & & 13.9 & 9.0 & & & \\
\hline
\end{tabular}

The potential of the variety manifested itself in 2017 with a yield of $53.6 \mathrm{cwt} / \mathrm{ha}$ in the experiments of Chelyabinsk RIA; $52.0 \mathrm{cwt} / \mathrm{ha}$ - at CJSC Kurgansemena; in $2018-61.3$ cwt/ha - in Omsk (SibRIA); $60.5 \mathrm{cwt} / \mathrm{ha}$ - in Novosibirsk (SibRIA); $56.7 \mathrm{cwt} / \mathrm{ha}$ - in AltaiRIA.

Testing in a dry year (2020) at SAU of the Kurgan region, Aist 45 variety in terms of yield was at the level of standards, exceeding them in some points.

Table 4. Productivity of varieties at SAU of Kurgan Region, 2020, cwt/ha.

\begin{tabular}{|c|c|c|c|c|c|c|c|c|}
\hline \multirow[b]{2}{*}{$\begin{array}{l}\text { Point } \\
\text { trials }\end{array}$} & \multirow[b]{2}{*}{$\begin{array}{c}\text { Aist } \\
45\end{array}$} & \multirow[b]{2}{*}{$\underset{\mathrm{a}}{\text { Radug }}$} & \multirow[b]{2}{*}{$\begin{array}{l}\text { Omska } \\
\text { ya } 35\end{array}$} & \multirow[b]{2}{*}{$\begin{array}{c}\text { Uralosi } \\
\text { birskay } \\
\text { a, st }\end{array}$} & \multirow[b]{2}{*}{$\begin{array}{c}\text { Gerakl, } \\
\text { st }\end{array}$} & \multicolumn{3}{|c|}{ Aist 45 c. St } \\
\hline & & & & & & $\begin{array}{c}\text { Uralosi } \\
\text { birskay } \\
\text { a }\end{array}$ & $\begin{array}{c}\text { Gerak } \\
1\end{array}$ & $\begin{array}{c}\mathrm{LSD}_{0} \\
5, \\
\mathrm{cwt} / \mathrm{h} \\
\mathrm{a}\end{array}$ \\
\hline Belozersk SAU & 22.7 & 24.8 & 26.0 & 21.5 & 2.5 & 1.2 & 2.5 & 1.0 \\
\hline Polovinsky SAU & 20.3 & 18.2 & 19.7 & 19.5 & 21.1 & 0.8 & -0.8 & 0.8 \\
\hline $\begin{array}{l}\text { Dalmatovskiy } \\
\text { SAU }\end{array}$ & 20.5 & 21.0 & 20.5 & 19.7 & 19.6 & 0.8 & 0.9 & 1.5 \\
\hline Kurtamysh SAU & 12.4 & 13.1 & 8.4 & 12.8 & 11.9 & -0.4 & 0.5 & 1.0 \\
\hline
\end{tabular}




\begin{tabular}{|l|c|c|c|c|c|c|c|c|}
\hline $\begin{array}{l}\text { Makushinsky } \\
\text { SAU }\end{array}$ & 20.5 & 14.6 & 14.1 & 20.8 & 17.1 & -0.3 & 3.4 & 0.9 \\
\hline Kurgan RIA & 22.9 & 22.0 & 20.9 & 20.9 & 17.3 & 2.0 & 5.6 & 1.9 \\
\hline Average & 19.9 & 19.0 & 18.3 & 19.2 & 17.9 & 0.7 & 2.0 & 1.2 \\
\hline
\end{tabular}

According to the complex of indicators of grain quality, Aist 45 variety belongs to valuable wheat (table 5). In the conditions of the Trans-Urals, the variety forms a wellmade grain with a weight of 1000 grains of 40-43 g, in drought conditions - 29-33 g, vitreousness - 52-65\%, gluten - not lower than the third class (25.2-33.4\%). These indicators can serve as relative indicators of drought resistance. The traits of grain quality obtained from sowing at different times are ambiguous, but on average over the years of research they are higher in the 2nd period, which is optimal for the zone.

Table 5. Quality indicators of Aist 45 variety by sowing dates 2017-2020.

\begin{tabular}{|l|c|c|c|c|c|c|c|c|c|c|}
\hline \multirow{2}{*}{ Indicator } & \multicolumn{2}{|c|}{2017} & \multicolumn{2}{c|}{2018} & \multicolumn{2}{c|}{2019} & \multicolumn{2}{c|}{2020} & \multicolumn{2}{c|}{$\overline{\mathrm{x}}$} \\
\cline { 2 - 14 } & 1 st * & 2nd * & 1 st & 2nd & 1 st & 2nd & 1 st & 2nd & 1 st & 2nd \\
\hline Flour output, \% & 76 & 78 & 70 & 69 & 68 & 75 & 71 & 69 & 71 & 73 \\
\hline Natural weight, & 688 & 760 & 777 & 734 & 776 & 745 & 763 & 750 & 757 & 758 \\
\hline Weight of 1000 & 40.0 & 40.0 & 43. & 39.0 & 40.3 & 43.8 & 29.0 & 33.0 & 38.1 & 39.0 \\
\hline Vitreousness, \% & 54 & 55 & 52 & 59 & 63 & 61 & 65 & 67 & 58 & 60 \\
\hline Gluten in flour, \% & 32.0 & 34.8 & 25. & 28.0 & 28.4 & 38.5 & 33.4 & 36.0 & 30.0 & 34.3 \\
\hline Flour strength, & 186 & 131 & 184 & 222 & 206 & 183 & 232 & 444 & 202 & 245 \\
\hline Bread volume, ml & 615 & 600 & 640 & 600 & 580 & 650 & 650 & 690 & 621 & 635 \\
\hline
\end{tabular}

* sowing term: 1st sowing - May 5-9, 2nd - May 18-20.

In the competitive variety testing over the past 3 years, Aist 45 exceeded the new variety of local selection Zauralochka in terms of gluten content by $5.6 \%$ and the standard Uralosibirskaya, included in the list of strong wheat, by $2.8 \%$. According to the content of crude protein, Aist 45 variety is at the standard level (table 6).

Table 6. Protein and gluten content in flour of Aist 45 variety, CVT (2nd sowing date), 2018-2020.

\begin{tabular}{|l|c|c|c|c|c|c|c|c|}
\hline \multirow{2}{*}{ Variety } & \multicolumn{3}{|c|}{ Gluten, \% } & \multicolumn{3}{c|}{ Protein, \% } & \multirow{2}{*}{$\overline{\mathrm{x}}$} \\
\cline { 2 - 3 } & 2018 & 2019 & 2020 & & 2018 & 2019 & 2020 & \\
\hline Aist 45 & 28.0 & 38.5 & 36.0 & 34.2 & 12.3 & 15.2 & 14.9 & 14.1 \\
\hline Uralosibirskaya, st. & 24.0 & 37.7 & 32.6 & 31.4 & 13.9 & 15.1 & 15.6 & 14.9 \\
\hline Zauralochka & 22.0 & 32.0 & 31.8 & 28.6 & 11.5 & 12.5 & 15.2 & 13.1 \\
\hline
\end{tabular}

According to the analysis results at KASIB test points, Aist 45 variety has a good potential for protein content up to $15.7-16.3 \%$ and gluten in grain up to $31.6-32.4 \%$ (Omsk SAU, Siberian RAI) with an average of 14, 1 and 27.5 (table 7).

Table 7. Protein and gluten content in Aist 45 grain by KASIB points, 2017-2020.

\begin{tabular}{|c|c|c|c|c|c|c|c|c|c|c|c|c|}
\hline \multirow{2}{*}{ Indicator } & \multicolumn{2}{|c|}{ Siberian RIA } & \multicolumn{2}{|c|}{$\begin{array}{c}\text { Pavlodar } \\
\text { RIA }\end{array}$} & \multicolumn{2}{c|}{ Altai RIA } & \multicolumn{2}{c|}{ Omsk SAU } & \multicolumn{3}{|c|}{ Kurgan RIA } & \multirow{2}{*}{$\overline{\mathrm{x}}$} \\
\cline { 2 - 15 } & 2017 & 2018 & 2017 & 2018 & 2017 & 2018 & 2017 & 2018 & 2018 & 2019 & 2020 & \\
\hline Protein, \% & 16.3 & 15.7 & 13.2 & 13.5 & 13.1 & 11.8 & 15.7 & 13.5 & 12.3 & 13.2 & 14.9 & 14.1 \\
\hline Gluten, \% & 32.4 & 31.6 & 26.1 & 27.6 & 27.0 & 26.9 & 31.6 & 26.3 & 24.5 & 22.4 & 25.9 & 27.5 \\
\hline
\end{tabular}


Brown and stem rust is considered to be one of the harmful diseases in the Trans-Urals [8]. The weather in 2015, 2016 and 2017 contributed to favorable conditions for the development of rust. Mid-season varieties suffered to a greater extent, since their biology coincided with the peak of the lesion. Being the standard in this group, Tertsiya variety has a resistance gene to leaf rust LrTR with a vertical resistance type. The variety has successfully passed the test and was included in the State Register of the Russian Federation for VI, IX and X regions in 1995. The varieties protected by this gene were widespread, but by 2016-2017 (rust epiphytotia), new virulent races appeared and the LrTR gene lost its effectiveness [9]. Against this background, Aist 45 variety showed resistance and tolerance to brown and stem rust, powdery mildew, which significantly increased its yield (table 8).

Table 8. Productivity and disease resistance of wheat varieties by sowing dates, $2016-2017$.

\begin{tabular}{|c|c|c|c|c|c|c|c|c|c|c|c|c|}
\hline \multirow{4}{*}{ Variety } & \multicolumn{6}{|c|}{ Productivity, cwt/ha } & \multicolumn{4}{|c|}{ Rust, score } & \multirow{2}{*}{\multicolumn{2}{|c|}{$\begin{array}{l}\text { Powdery } \\
\text { mildew, } \\
\text { score }\end{array}$}} \\
\hline & \multicolumn{2}{|c|}{ 2nd term } & \multicolumn{2}{|c|}{ 3rd term } & \multirow{3}{*}{$\bar{x}$} & \multirow{3}{*}{$\begin{array}{l}\text { Aist } \\
45 \text {, } \\
\pm \text { c. st }\end{array}$} & \multirow{3}{*}{\begin{tabular}{|l} 
brown \\
2016
\end{tabular}} & \multicolumn{3}{|c|}{ stem } & & \\
\hline & \multirow{2}{*}{2016} & \multirow{2}{*}{2017} & \multirow{2}{*}{2016} & \multirow{2}{*}{2017} & & & & \multirow{2}{*}{2016} & \multicolumn{2}{|c|}{2017 , term } & \multirow{2}{*}{2016} & \multirow{2}{*}{2017} \\
\hline & & & & & & & & & 2nd & $3 \mathrm{rd}$ & & \\
\hline \multicolumn{13}{|c|}{ mid-ripening } \\
\hline Aist 45 & 32.8 & 46.2 & 7.2 & 20.4 & 28.0 & +12.7 & 3 & 2 & 1 & 1 & 2 & 0 \\
\hline Terzia, st & 22.7 & 35.1 & 1.3 & 2.3 & 15.3 & $\mathrm{St}$ & 4 & 4 & 4 & 3 & 4 & 2.5 \\
\hline \multicolumn{13}{|c|}{ mid-late } \\
\hline $\begin{array}{l}\text { Omskaya } \\
35, \text { st }\end{array}$ & 28.2 & 39.0 & 5.4 & 6.4 & 19.7 & +8.3 & 4 & 3.5 & 2 & 4 & 1 & 2 \\
\hline Raduga & 36.4 & 51.2 & 12.4 & 20.6 & 30.1 & -1.9 & 3.5 & 1.5 & 1.5 & 2.5 & 1 & 2 \\
\hline
\end{tabular}

*2nd sowing date - May 18-22; 3rd sowing date - June 10

According to the assessment results for resistance to brown rust on an artificial background in the seedling phase (VIZR and VNIIF), Aist 45 variety was classified as a resistant type (Table 9).

Table 9. Aist 45 variety resistance to brown rust, VIZR, 2017.

\begin{tabular}{|c|c|c|c|c|c|c|c|}
\hline \multirow{2}{*}{ 27/07 1.f. } & \multirow{2}{*}{ 10/08 1.f. } & \multirow{2}{*}{ 17/08 1.f. } & \multicolumn{4}{|c|}{$\begin{array}{l}\text { Isolates of the causative agent of brown rust } \\
\text { (seedling inoculation) }\end{array}$} & \multirow[t]{2}{*}{ VNIIF } \\
\hline & & & $\mathrm{k} 9$ & k19 & k26 & $\mathrm{kNW}$ & \\
\hline 0 & 0 & $1-5 \mathrm{MR}$ & 0 & 0 & $3-4$ & 0 & 5 \\
\hline
\end{tabular}

The variety is protected by the Lr26 gene. According to genetic studies, this gene is linked to the $\mathrm{Sr} 31$ gene (resistance to stem rust), as well as to the Yr9 gene (resistance to yellow rust) and Pm8 (resistance to powdery mildew) [10]. The Sr31 gene is not effective against the Ug99 race but provides protection against populations of stem rust pathogen in the Russian Federation. The formula of the identified resistance genes: Lr26 / Sr31 / Yr9 / Pm8. When tested in Kenya against the background of artificial infection, the variety showed susceptibility to the local race of stem rust and a relative resistance to yellow rust 1 MS (table 10).

Table 10. Resistance of Aist 45 variety to rust, KALRO, Kenya.

\begin{tabular}{|c|c|c|c|c|}
\hline \multicolumn{2}{|c|}{ Stem Rust, SR KALRO, Kenya } & \multicolumn{2}{c|}{ Yellow rust, YR, KALRO, Kenya } \\
\hline $26 / 9 / 2017$ & $04 / 10 / 2017$ & $10 / 10 / 2017$ & $30 / 8 / 2017$ & $06 / 9 / 2017$ \\
\hline $10 \mathrm{M}$ & $30 \mathrm{MSS}$ & $70 \mathrm{~S}$ & $1 \mathrm{MS}$ & $1 \mathrm{MS}$ \\
\hline
\end{tabular}


Against the infectious background of the Research Institute of Biological Safety Problems of South Kazakhstan, Aist 45 variety showed resistance to septoriosis and pyrenophorosis. Susceptible to dust brand.

In KRIAP (Alma-Aty) NDVI (vegetation index) was determined. Index values range from 0.20 to 0.95 . The better the vegetation is during the growing season, the higher the NDVI. With the NDVI $=0.74$, Aist 45 variety ranks second among 52 varieties studied under the KASIB program.

\section{Conclusion}

Thus, a feature of Aist 45 variety is the ability to form a stable yield under stressful conditions of drought and epiphytotic development of brown and stem rust. Against the provocative backgrounds of stubble sowing and late sowing (June 10), the variety showed a higher yield and plasticity compared to the standards. Aist 45 is resistant in relation to pathogens. The variety is valuable in terms of grain quality, successfully realizes its genetic potential in various growing conditions. It is able to arouse commercial interest among agricultural producers.

\section{References}

1. V.V. Novokhatin, Agricultural Biology 5 (51), 627-635 (2016)

2. V.A. Telegin et al. Improving the efficiency of agriculture in the Trans-Urals in dry conditions, 229 (2013)

3. P.V. Popolzukhin, V.D. Vasilevsky, E.S. Kuzmina, Rural Siberia 2 (02), 38-42 (2017)

4. A. G. Kryuchkov, Bulletin of Orenburg SAU 3, 1 (35), 41-44 (2012)

5. A.V. Titarenko, N.A. Korobova, Grain farming of Russia 3, 41-45 (2013)

6. B.A. Dospekhov, Field experiment methodology (with the basics of statistical processing of research results), 352 (2012)

7. L.T. Maltseva, E.A. Filippova, N.Yu. Bannikova, V.A. Berdyugin, Feed production 11, 27-31 (2018)

8. V.P. Shamanin [et al.], Breeding of soft spring wheat for resistance to stem rust in Western Siberia, 21 (2015)

9. L.T. Maltseva, E.A. Filippova, N.Yu. Bannikova. Bulletin of Omsk State Agrarian University 1 (33), 21-30 (2019)

10. E.I. Gultyaeva, E.L. Shaydayuk, V.P. Shamanin et al., Agricultural Biology, 53(1), 8595 (2018) 